\title{
Non-Linearity Effect of Low-Doses $\gamma$-Radiation on Essential Metals, Lipid Peroxidation and Metallothionein Levels in Rats
}

\author{
A. M. Hawas and A. A. Saad-El-Din* \\ Radiation Drug Research and "Radiation Physics Dept., \\ National Centre for Radiation Research and Technology \\ (NCRRT), P. O. Box; 29 Nasr City, Egypt.
}

\begin{abstract}
T OW DOSES increase the resistance of the cells or Jorganism to the moderate or severe levels of stress. The present work aimed to investigate the effect of low $\gamma$-radiation doses on the essential metals; iron, copper, zinc and calcium ( $\mathrm{Fe}, \mathrm{Cu}, \mathrm{Zn} \& \mathrm{Ca}$ ), lipid peroxidation as malondialdehyde (MDA) and metallothionein (MT) in the liver, kidney and testis of rats. Rats were exposed to $0.06,0.126$ and 0.227 Gy at a low dose rate $2.5 \mathrm{mGy} / \mathrm{h}$ by two models of exposure, continuous and fractionated (along one and two weeks). The results indicated significant effect between groups and time of exposure models. Trace metals exhibited difference responses in the different tissues particularly before and after 0.126 Gy dose, but certain metals tended to restore the normal levels in continuous and fractionated for one week exposure models at 0.227 Gy. After two weeks increasing in $\mathrm{Ca}$ and decreasing in Fe levels and MT levels were observed at the all doses. Zinc levels had not been affected in kidney and testis, controversy effects occurred in liver which increased at $0.227 \mathrm{~Gy}$ in all exposure models. Continuous exposure led to elevation in MDA and lowering in MT at 0.126 Gy then reverse effect occurred at 0.227 Gy. In conclusion, low doses $\gamma$-radiation exposure has no-linear effect on the essential metals, lipid peroxidation and MT.

Keywords: Low doses, $\gamma$-radiation, essential metals, lipid peroxidation, metallothionein,.
\end{abstract}

Living organisms are constantly exposed to ionizing radiations from the natural sources such as cosmic rays, radio-nuclides present in the earth's crust or man made medical and industrial radiation sources, nuclear exposures, industrial accidents and others. The United Nation Scientific Committee on the Effects of Atomic Radiation (UNSCEAR) reported in 1986, that acute doses above 2.0Gy, 
between 2 and 0.2Gy and below 0.2Gy are regarded as high, intermediate and low doses respectively (UNSCEAR, 1986). The high doses of $\gamma$-radiation caused deleterious effects via the oxidative stress by reactive oxygen species (ROS) formation and liberation excess of free radicals which attack cell content of molecules and organelles. This damaged effect lead to high disturbances in the physiological and biochemical functions in animals and human including imbalance in essential trace elements which required by all cells for normal metabolic processes, and are constituents of or interact with antioxidant enzymes and hormones (Mertz, 1981) and stored in the appropriate tissues as MT and ferritin (Sorenson, 1978). Trace elements play an important role in human health and disease. It participates in tissue, cellular and subcellular functions, includes immuno-regulation by both humeral and cellular mechanism, nerve conduction, muscle contraction, membrane potential regulation and mitochondrial activity, among others (Agget and Devis, 1983 and Golden, 1982).

The deleterious effects due to low radiation dose are theoretically extrapolated from the high dose by the Linear No-Threshold (LNT) model (Pathak et al., 2007). However living organisms do not respond to ionizing radiations in a linear manner in the low dose range $0.01-0.50 \mathrm{~Gy}$ and rather restore the homeostasis both in vitro and in vivo by the normal repair processes such as DNA repair processes, immune reactions and antioxidant defence (Avti et al., 2005 and Pollycove, 2004), adaptive responses (Wang et al., 2004) and activation of immune functions (Feinendegen, 2005 and Feinendegen et al., 2010). The general hypothesis of radiation stimulated beneficial changes in known as Adaptive Responses and idea of net benefit is called Hormesis (Pathak et al., 2007 and Wall et al., 2006). Hormesis is a dose-response relationship in which effects at low doses are opposite to those at high doses (Hoffmann, 2009).

In the present study, we have attempt to investigate the effect of acute and fractionated very low doses of $\gamma$-radiation on the essential metals; $\mathrm{Fe}, \mathrm{Cu}, \mathrm{Zn} \&$ $\mathrm{Ca}$ levels and on the oxidative process, lipid peroxidation and antioxidant hormone, MT in the liver, kidney and testis of rats.

\section{Material and methods}

\section{Animals and irradiation}

Male albino Wistar rats weighing 120-150g were kept in plastic cages and were allowed free access to water and normal pellet diet and were maintained Egypt. J. Rad. Sci. Applic., Vol. 24, No. 1 (2011) 
under controlled conditions of humidity, temperature and a diurnal environment of light and dark. Galvanized cylindrical metal cages of double walls at 32 and $48 \mathrm{~cm}$ diameter $\mathrm{x} 22 \mathrm{~cm}$ height, especially designed for this experiment.

The rats were kept between the two walls of the cage which the middle axis of the cage was approximately at $20 \mathrm{~cm}$ from the source, taking in consideration the width between the two walls is $8 \mathrm{~cm}$. Low dose rate ${ }^{137}$ Cesium source of $2.5 \mathrm{mGy} / \mathrm{h}$ belonging to NCRRT, Cairo, Egypt.

Animals were divided into control (non irradiated animals) and another three groups: the first group was exposed continuously to whole body $\gamma$-rays. The second group was exposed along one week and the third group was exposed along two weeks to whole body fractionated dose of $\gamma$-radiation. Each group was subdivided into three subgroups; the first, second and third were exposed to $0.06,0.126$ and $0.227 \mathrm{~Gy}$ for 24,50 and $90 \mathrm{~h}$, respectively at a low dose rate $2.5 \mathrm{mGy} / \mathrm{h}$. The fractionated doses, where rats exposed to $\gamma$-ray by the same times daily to reach the certain dose $0.06,0.126$ or $0.227 \mathrm{~Gy}$ at the end of the one or the two weeks. At each scarified $n=8$.

\section{Trace metals analysis}

$\mathrm{Fe}, \mathrm{Cu}, \mathrm{Zn} \& \mathrm{Ca}$ concentrations were measured in the liver, kidney and testis tissues. For the digestion process using Milestone MLS-1200 Mega, High Performance Microwave Digestor Unit, Italy. 0.5-1g of organs was put in special vessels with $6 \mathrm{ml}$ nitric acid and $1 \mathrm{ml}$ hydrogen peroxide. After complete digestion, samples were diluted to suitable levels for metals analysis by UNICAM 939 Atomic Absorption Spectrophotometer (AAS), England).

\section{Lipid peroxidation determination}

Lipid peroxidation levels were ascertained by the formation of MDA. Sample preparation was performed as described by Sander et al. (1996). $0.5 \mathrm{ml}$ of liver, kidney and testis homogenate was treated for determination of MDA as described by Yoshioka et al. (1979).

\section{Metallothionein determination}

MT levels were determined in the liver, kidney and testis by Ag-saturation haemolysate method according to Bienengraber et al. (1995) and Scheuhammer and Cherian (1986). 


\section{Statistical analysis}

Data were analyzed by unpaired two-tailed Student's t-test (Kirkwood, 1988 ) and one way analysis of variance (ANOVA). $P$ values $\leq 0.05$ was considered significant. The results were presented as mean \pm S.E.

\section{Results}

Results analysis exhibited significant effect of low $\gamma$-radiation doses $\quad(P \leq$ 0.05) on essential metals, MDA and MT levels. Also there was very high significant relationship between the groups and/or the time models in the organs studied with exception of $\mathrm{Zn}$ in kidney, and there was no relationship present between the effect of time and groups in $\mathrm{Cu}$ testis or between groups in $\mathrm{Zn}$ testis.

The figures describe the metals ( $\mu \mathrm{g} / \mathrm{g}$ wet tissues), MDA (nmol/g wet tissues) and MT ( $\mu \mathrm{g} / \mathrm{g}$ wet tissues) levels in rat liver, kidney and testis (mean \pm S.E.) in the models of exposure, continuous or fractionation (for one and two weeks) at $0.06,0.126$ and $0.227 \mathrm{~Gy}$ (at a low dose rate $2.5 \mathrm{mGy} / \mathrm{h} 0$ ).

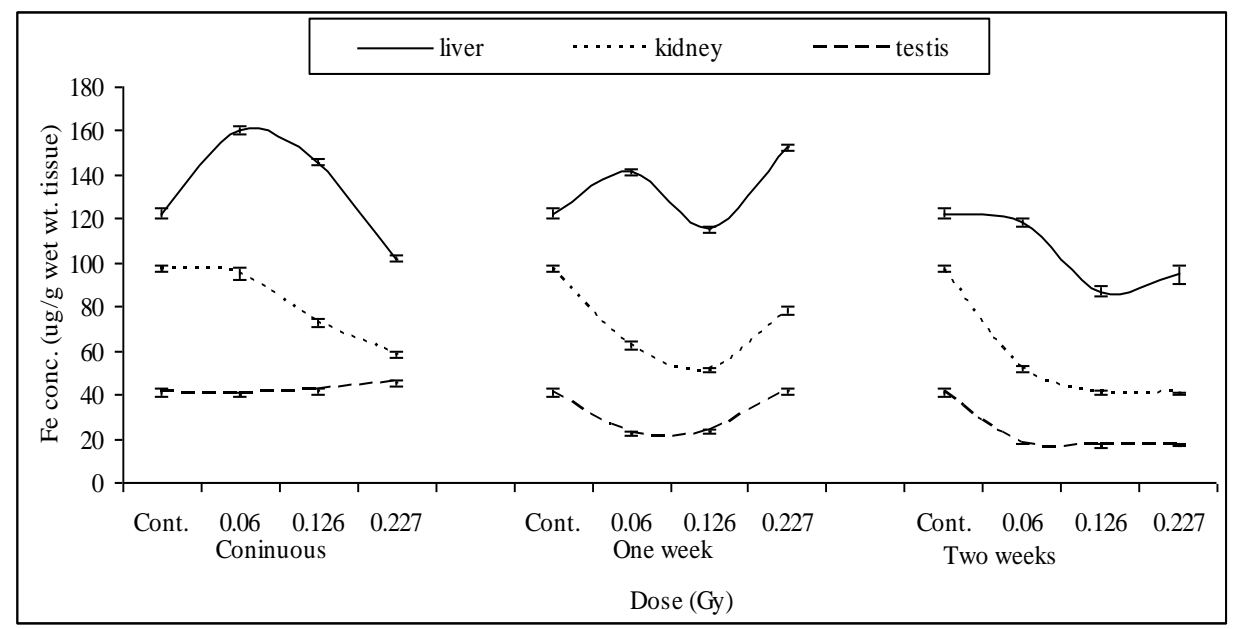

Fig. 1. Low doses $\boldsymbol{\gamma}$-radiation effect on Fe levels of rat liver, kidney and testis.

Fig.1. shows the Fe levels: Significant increase $(P \leq 0.05)$ occurred in $\mathrm{Fe}$ levels in liver due to the continuous exposure for 24 and $50 \mathrm{~h}$ (0.06 and $0.126 \mathrm{~Gy}$, respectively) and lowered after $90 \mathrm{~h}$ exposure $(0.227 \mathrm{~Gy})$. In kidney, Fe levels significantly decreased post 50 and $90 \mathrm{~h}$ but testis had not been affected. Fractionation of the same doses for one week caused significant decrease in all organs after exposure to total dose $0.126 \mathrm{~Gy}$, while there was an Egypt. J. Rad. Sci. Applic., Vol. 24, No. 1 (2011) 
increase before and after the same dose in liver. Kidney and testis Fe levels decreased at 0.06 and $0.126 \mathrm{~Gy}$ then at $0.227 \mathrm{~Gy}$, kidney $\mathrm{Fe}$ started to return control levels and testis restore control levels via one week fractionated dose. Two weeks of exposure indicated lowering in Fe levels in all organs.

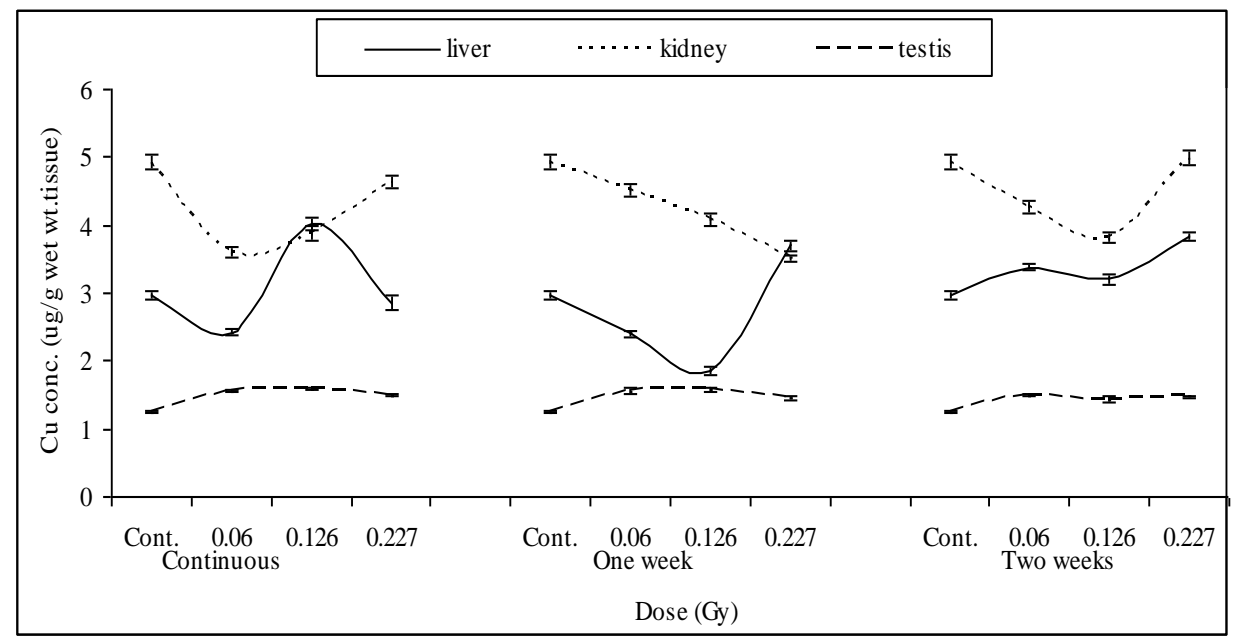

Fig. 2. Low doses $\gamma$-radiation effect on Cu levels of rat liver, kidney and testis.

Fig.2. shows the $\mathrm{Cu}$ levels: Significant decrease $(P \leq 0.05)$ in $\mathrm{Cu}$ liver level occurred after $24 \mathrm{~h}$ continuous exposure, and it increased at $50 \mathrm{~h}$ then back to normal level after $90 \mathrm{~h}$ exposure.

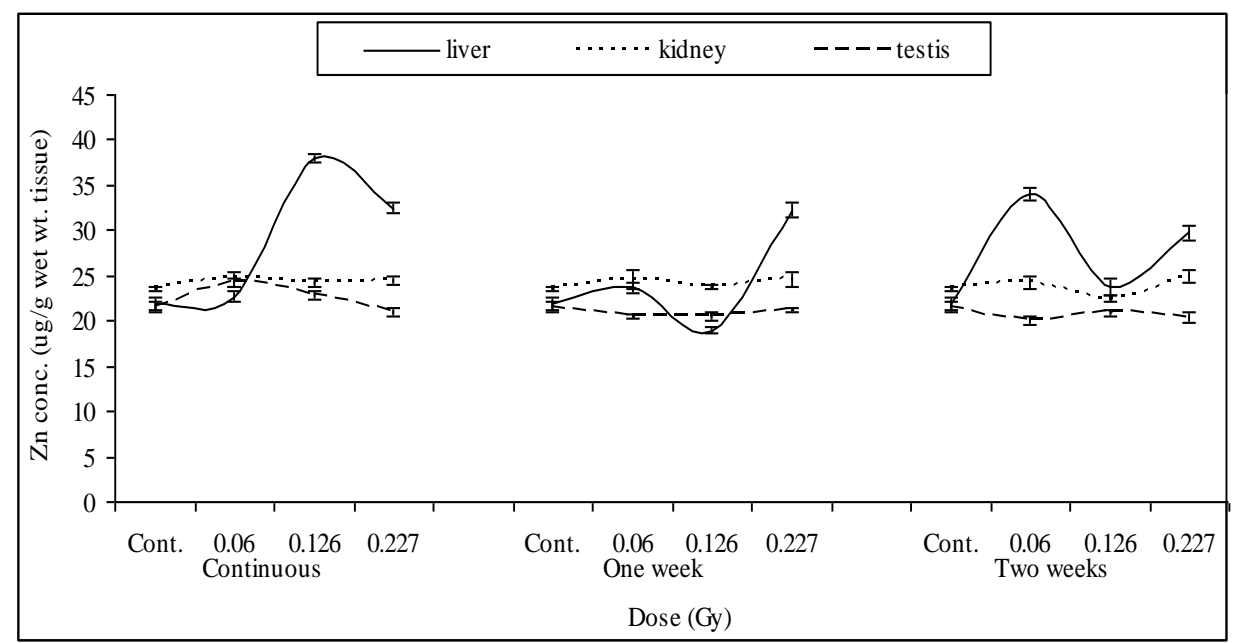

Fig. 3. Low doses $\gamma$-radiation effect on $\mathrm{Zn}$ levels of rat liver, kidney and testis.

Egypt. J. Rad. Sci. Applic., Vol. 24, No. 1 (2011) 
During fractionated doses for one week, there was significant decrease in $\mathrm{Cu}$ liver levels then elevated after $90 \mathrm{~h}$ exposure and elevation was detected at all doses after two weeks exposure. Kidney $\mathrm{Cu}$ exhibited severe decreasing at $0.06 \mathrm{~Gy}$, then restore control levels at $0.227 \mathrm{~Gy}$ after continuous and two weeks exposure, but there was significant decreasing along one week exposure. Stable increase response was observed in testis cu levels in all exposure models.

Fig.3. shows the Zn levels: Only, a liver $\mathrm{Zn}$ level was affected along the different models of exposure. After continuous exposure, liver $\mathrm{Zn}$ showed a significant increase $(\mathrm{P} \leq 0.05)$ at $0.126 \mathrm{~Gy}$ and tends to return control levels at $0.227 \mathrm{~Gy}$. One week exposure led to lowering in liver $\mathrm{Zn}$ at $0.126 \mathrm{~Gy}$ then elevated at $0.227 \mathrm{~Gy}$. Different effect was detected after two week exposure while liver $\mathrm{Zn}$ levels increased at 0.06 and $0.227 \mathrm{~Gy}$ and no significant effect at $0.126 \mathrm{~Gy}$. Non significant change was observed in kidney and testis at all doses (except at 0.06Gy in testis).

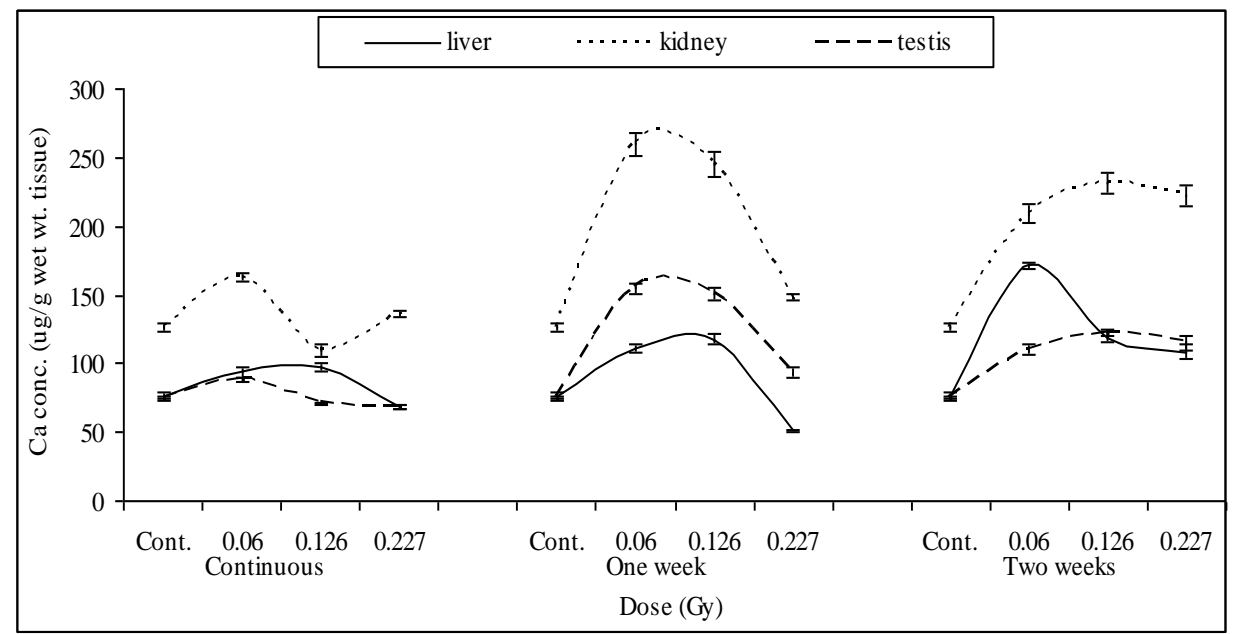

Fig. 4. Low doses $\gamma$-radiation effect on Ca levels of rat liver, kidney and testis.

Fig.4. shows the Ca levels: It was observed that $\mathrm{Ca}$ levels elevated in all organs studied after $24 \mathrm{~h}$ of continuous exposure and there was different response after $50 \mathrm{~h}$, significant increase $(P \leq 0.05)$ in liver and decrease in kidney Ca levels. After $90 \mathrm{~h}$ lowering in Ca levels in liver and testis but it increased in kidney. The exposure to fractionated low doses across one and two weeks resulted in significant increase in $\mathrm{Ca}$ levels in the organs studied. On the other hand, its levels tend to restore control levels after exposure to $90 \mathrm{~h}$ for one week, while it lowered in liver.

Egypt. J. Rad. Sci. Applic., Vol. 24, No. 1 (2011) 


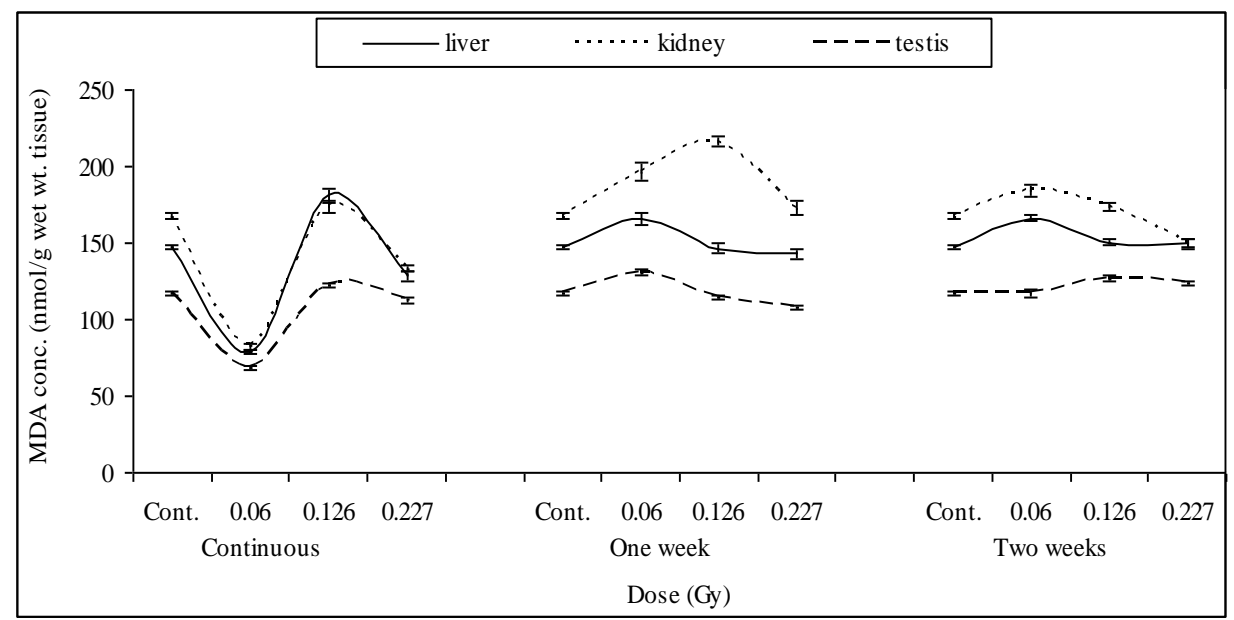

Fig. 5. Low doses $\gamma$-radiation effect on MDA levels of rat liver, kidney and testis.

Fig.5. shows the MDA levels: the continuous exposure to 0.06Gy caused high significant decrease $(P \leq 0.05)$ in MDA levels in the all organs studied, and then caused increasing in liver and testis at $0.126 \mathrm{~Gy}$ compared to control and inhibition occurred in liver and kidney at $0.227 \mathrm{~Gy}$ doses. The fractionated dose 0.06Gy for one week resulted in increase in MDA in the all organs studied, and in kidney at $0.126 \mathrm{~Gy}$ doses. At the $0.227 \mathrm{~Gy}$ dose, liver and kidney return control levels and decreasing in testis occurred. After two weeks, significant elevation in MDA observed in liver and kidney at $0.06 \mathrm{~Gy}$, and in testis at 0.126 and $0.227 \mathrm{~Gy}$ doses, and kidney level decreased at $0.227 \mathrm{~Gy}$.

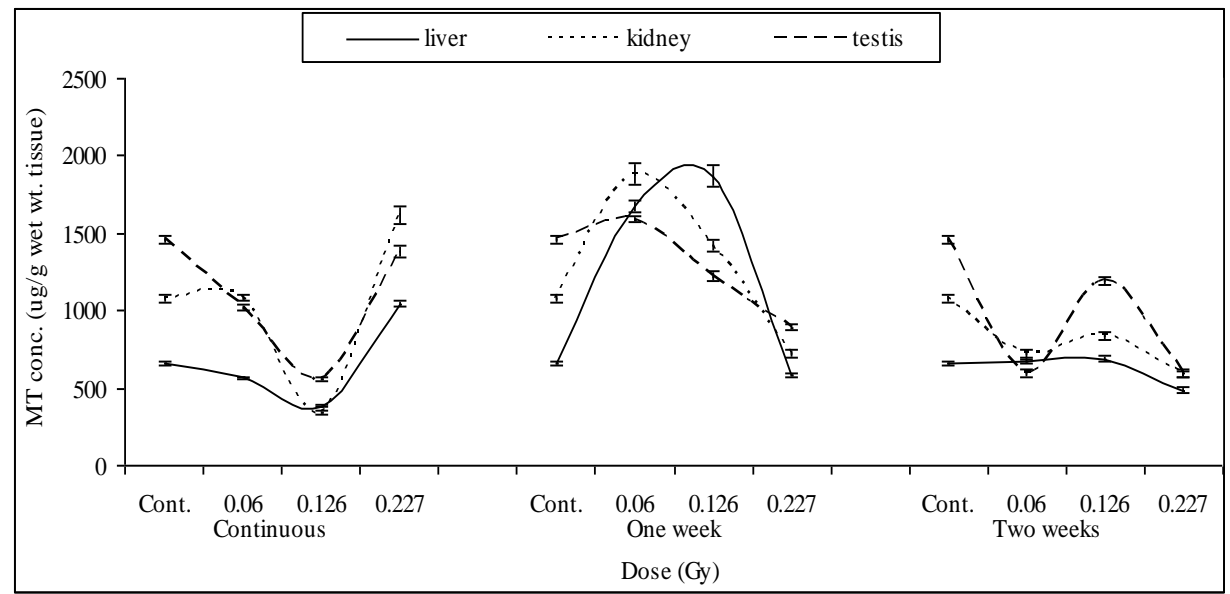

Fig. 6. Low doses $\gamma$-radiation effect on MT levels of rat liver, kidney and testis.

Egypt. J. Rad. Sci. Applic., Vol. 24, No. 1 (2011) 
Fig.6. shows the MT levels: there was a clear different response in the different modes of exposure. The continuous exposure caused high significant inhibition $(P \leq 0.05)$ in MT-induction at $0.126 \mathrm{~Gy}$ dose in all organs studied, then highly significant elevated at $0.227 \mathrm{~Gy}$ doses in the liver and kidney. Fractionated doses for one week indicated inverted effect, while the highest dose 0.227Gy resulted in high significant decrease in MT levels. After two weeks, high disturbance occurred in its levels, generally significant decrease was observed up to $90 \mathrm{~h}$ exposure.

\section{Discussion}

The understanding of radiation biology has undergone a fundamental shift in paradigms away from deterministic "hit-effect" relationship and towards complex ongoing cellular responses (Pathak et al., 2007). Any increment of exposure above natural background levels of radiation will produce a linear increment of risk, the so-called LNT model. The LNT hypothesis has been attacked both by those who believe that low doses of radiation are more damaging than the hypothesis predicts, and by those who believe that they are less harmful and possibly even beneficial, which referred to as hormesis (Wall et al., 2006). In a complex biological system various mechanisms can lead to non linearity, deviations from linearity are favoured by the occurrence of multiple concurrent and sequential events in toxicologic responses (Hoffmann, 2009). Cells can be injured and even killed under the most serious conditions of radiation exposure, when the content of ROS gets uncontrolled by the cellular antioxidants, it is believed that the extent of cellular damage by low-radiation doses is proportional to the effects observed at high-radiation doses as per the LNT hypothesis. However, this notion may not be true at low-dose radiation exposure in the living systems (Feinendegen, 2005). Hormesis is well-documented at the phenomenological level and it increasingly appears to be a manifestation of a broad family of stress responses (Calabrese et al., 2007) including adaptive responses and preconditioning. The results of the present work reflected different responses by different models of exposure to low doses $\gamma$-ray as continuous or fractionated exposure and according to the tissue type. The studied organs, liver, kidney and testis manifested respective effect under the stresses of low-radiation doses $(0.06$, 0.126 and $0.227 \mathrm{~Gy}$ at a low dose rate $2.5 \mathrm{mGy} / \mathrm{h}$ ). The effects on metals level elicited different responses before and after the $0.126 \mathrm{~Gy}$ dose by decreasing and Egypt. J. Rad. Sci. Applic., Vol. 24, No. 1 (2011) 
increasing according to the sensitivity of the elements and its reactions in the organs, such as the effect of continuous exposure on liver $\mathrm{Fe}$ and $\mathrm{Cu}$ and fractionated exposure for one week on $\mathrm{Fe}, \mathrm{Ca}$ and MT of liver, kidney and testis. The adaptive protection following low doses of low-LET (Linear Energy Transfer) radiation appears to be the consequence of changed cellular signaling and to be ubiquitous (Feinendegen, 2005). Hormetic response curves are biphasic, the biphasic curve is so central that hormesis is often defined with respect to a dose-response curve that is essentially J-shaped or an inverted-U (Calabrese and Baldwin, 2002 and Davis and Svendsgaard, 1990). This respective response clearly appeared in the graphs in the different models of exposures. According to Edward (1990), the accumulation of Fe in liver post-high dose of radiation via occlusion of the small hepatic veins leading to hemorrhage, and the total $\mathrm{Zn}$ content increased in the liver and kidney (Okada, 1970 and Shiraishi et al., 1986) and rapid disappearance of $\mathrm{Ca}$ from the blood was observed after high doses of radiation. But after low doses of radiation, $\mathrm{Fe}$ and $\mathrm{Cu}$ levels were highly decreased in kidney which they have been non-linearity responses. On the other hand, kidney $\mathrm{Cu}$ in the continuous and fractionated along two weeks exposure models and $\mathrm{Fe}$ in the fractionated dose for one week model tends to restore normal levels. The studied essential trace elements and MDA and MT levels exhibited non-linear responses whereas these responses showed either J-shaped or inverted-U shaped curves as biphasic curves and triphasic wave. According to Calabrese and Baldwin (2003) and Hoffmann and Stempsey (2008), at the Jshaped or inverted-U shaped curves; the effect of the J-shaped curve is some dysfunction such as carcinogenesis, where the hormotic zone shows a frequency less than that occurring spontaneously with no exposure such as the continuous exposure effect on liver $\mathrm{Zn}$ until $0.126 \mathrm{~Gy}$ then decreasing occurred to restore normal levels whereas opposite response appeared in the fractionated dose for one week and two weeks, its levels elevated at $0.227 \mathrm{~Gy}$. If the end point were a normal biological function, such as growth, the hormetic curve would appear as an inverted-U shaped curve, in which the hormetic zone is represented by effects above the background level and the toxic zone by effect below it (Calabrese and Baldwin, 2003 and Hoffmann and Stempsey, 2008). Ca and MT levels showed inverted-U shaped curve response in the fractionated exposure for one week. MTinduction was highly decreased after exposure to $0.227 \mathrm{~Gy}$ in the fractionated for

Egypt. J. Rad. Sci. Applic., Vol. 24, No. 1 (2011) 
one week and two weeks models of exposure. Depending on type of adaptive protective in a given cell system such as damage prevention, repair, removal by apoptosis and stimulation of immune response, protection, cell cycle or changes in gene expression occur in most mammalian cells so for examined the expression of adaptive protection has a maximum above $0.005 \mathrm{~Gy}$ and below $0.2 \mathrm{~Gy}$ (Pollycove and Feinendegen, 2003 and Feinendegen 2003). The expanding triphasic wave appeared in $\mathrm{Zn}$ liver in the fractionated models may be a doseresponse relationship where hypothetical triphasic curve may occur if an agent causes damage and an inducible repair response at low doses (Hoffmann, 2009). Damage prevention by stimulation of detoxification of ROS appears to reach a maximum at about $4 \mathrm{~h}$ after irradiation and lasts for several hours or even weeks depending on tissue and cell type. The immune response had its maximum in vivo at about $0.2 \mathrm{~Gy}$ low-dose induced immune competence may last for several weeks (Feinendegen, 2005). At 0.06Gy, the major of results obtained via different models of exposure manifested severe effect by decreasing or increasing then start to return. At low dose rate the assumption of linearity may be valid only at doses above about $0.1 \mathrm{~Gy}$ with some variation in different tissue types and below this level radiation-induced effects dominate risk (Mitchel, 2007). Adaptive protection develops with a delay of hours, may last for days to months, decreases steadily at doses above about 0.1 to $0.2 \mathrm{~Gy}$ and is not observed any more after acute exposure of more than about 0.5Gy (Feinendegen, 2005). The effect of the low $\gamma$-radiation doses on trace metals in organs manifested no accumulations or continuously increasing or decreasing, but they mostly appeared to return its normal levels with certain exceptions which observed after two weeks exposure. Also in the different models of exposures, continuous or fractionation exposure, it is observed that its responses have been independent and not proportional to the dose level or the exposure time and they give various behaviours in the different organs. Moreover, the effects before and after the medial dose 0.126Gy were different in the most models studied. MT is antioxidant protein presence in the cells particularly of liver and kidney for metals detoxification, homeostasis and in scavenging free radicals during oxidation damage (Cai et al., 1999). MT-induction response due to low $\gamma$-radiation doses gives different track in each exposure model, its elevations in liver and kidney via continuous exposure to $0.227 \mathrm{~Gy}$ may be induced by the highly enhancement of MDA at $0.126 \mathrm{~Gy}$. Its elevations after

Egypt. J. Rad. Sci. Applic., Vol. 24, No. 1 (2011) 
exposure to fractionated dose for one week at 0.06 and $0.126 \mathrm{~Gy}$ may be a direct facing response against oxidative stress, and its decrease at $0.227 \mathrm{~Gy}$ which meet normal levels of MDA may account adaptive response where the repair in response to radiation damage begins immediately after damage has occurred (Feinendegen, 2005). We concluded that the essential metals; $\mathrm{Fe}, \mathrm{Cu}, \mathrm{Zn} \& \mathrm{Ca}$ and MDA and MT levels are very sensitive to the low doses of $\gamma$-radiation. Furthermore there are different effectiveness according to the time and the models of exposure either continuous or fractionated. Low doses $\gamma$-radiation exposure has no-linear effect on the essential metals, lipid peroxidation and MT levels.

\section{Acknowledgment}

This study was performed in the NCRRT, Egypt. We thank Assistant lecturer Hoda Hassan for helping us in the irradiation processes.

\section{References}

Agget, R. J. and Davis, N. T. (1983) Some nutritional aspects of trace metals. $J$. Inherit. Metab. Dis., 6(suppl 1): 22.

Avti, P. K., Pathak, C. M., Kumar, S., Kaushik, G., Kaushik, T., Farooque, A., Khanduja, K. L. and Sharma, S. C. (2005) Low dose gamma-irradiation differentially modulates antioxidant defense in liver and lungs of Balb/c mice. Int. J. Radiat. Biol., 81, 901.

Bienengräber, M., Forderkunz, S., Klein, D. and Summer, K. H. (1995) Determination of $\mathrm{Cu}$-containing metallothionein: comparison by $\mathrm{Ag}$ saturation assay, thiomolybdate assay and enzyme-linked immuonosorbent assay. Anal. Biochem., 228, 69.

Cai, L., Satoh, M., Tohyama, C. and Cherian, M. G. (1999) Metallothionein in radiation exposure: its induction and protective role. Toxicol., 132, 85.

Calabrese, E. and Baldwin, L. A. (2002) Defining hormesis. Hum. Exp. Toxicol., 21, 91.

Calabrese, E. J. and Baldwin, L. A. (2003) Hormesis: The dose-response revolution. Annu. Rev. pharmacol. Toxicol., 43, 175.

Calabrese, E. J., Bachmann, K. A., Bailer, A. J., Bolger, P. M., Borak, J., Cai, L., Cedergreen, N., Cherian, M. G., Chiueh, C. C., Clarkson, T. W., Cook, R. R., Diamond, D. M., Doolittle, D. J., Dorato, M. A., Duke, S. O., Feinendegen, L., Gardner, D. E., Hart, R. W., Hastings, K. L., Hayes, A. W., Hoffmann, G. R., Ives, J. A., Jaworowski, Z., Johnson, T. E., Jonas, W. B., Kaminski, N. E., Keller, J. G., Klaunig, J. E., Knudsen, T. B., Kozumbo, W. J., Lettieri, T., Liu, S. Z., Maisseu, A., Maynard, K. I., Masoro, E. J., McClellan, R. O., Mehendale, H. M., Mothersill, C., Newlin, D. B., Nigg, H. N., Oehme, F. W., Phalen, R. F., Philbert, M. A., Rattan, S. 
I., Riviere, J. E., Rodrick, J., Sapolsky, R. M., Scott, B. R., Seymour, C., Sinclair, D. A., Smith-Sonneborn, J., Snow, E. T., Spear, L., Stevenson, D. E., Thomas, Y., Tubiana, M., Williams, G. M. and Mattson, M. P. (2007) Biological stress response terminology: Integrating the concepts of adaptive response and preconditioning stress within a hormetic dose-response framework. Toxicol. Appl. Pharmacol., 222, 122.

Davis, J. M. and Svendsgaard, D. J. (1990) U-shaped dose-response curves: their occurrence and implications for risk assessment. J. Toxicol. Environ. Health, 30, 71 .

Edward, L. A. (1990) Late effects of radiation on normal tissues, Nonstochastic effects. In: Radiation biophysics. Prentice-Hall, Inc., pp. 227-254.

Feinendegen, L. E. (2003) Relative implications of protective response versus damage induction at low dose and low-dose-rate exposures, using the microdose approach. Radiat. Prot. Dosim., 104, 337.

Feinendegen, L. E. (2005) Evidence for beneficial low level radiation effects and radiation hormesis. Brit. J. Radiol., 78, 3.

Feinendegen, L. E., Pollycove, M. and Neumann, R. D. (2010) Low-dose cancer risk modeling must recognize up-regulation of protection. Dose-Response, 8, 227.

Golden, M. H. (1982) Trace elements in human nutrition. Hum. Nutr. Clin. Nutr., 36, 185.

Hoffmann, G. R. (2009) A perspective on the scientific, philosophical, and policy dimensions of hormesis. Dose-Response, 7, 1.

Hoffmann, G. and Stempsey, W. (2008) The hormesis concept and risk assessment: Are there unique ethical and policy consideration? Hum. Exp. Toxicol., 27, 613.

Kirkwood, B. R. (1988) Comparison of two means. In: Kirkwood, B.R. (ed.), Essentials of medical statistics. Blackwell Scientific Publications, pp. 41-45.

Mertz, W. (1981) The essential trace elements. Science, 213, 1332.

Mitchel, R. E. (2007) Low dose of radiation reduced risk in vive. Dose-Response, 5, 1.

Okada, S. (1970) Radiation-induced death. In: Altman, K.I., Gerber, G.B. Okada, S. (Eds.), Radiation biochemistry. Vol. I., Academic Press. N.Y., pp. 247-307.

Pathak, C. M., Avti, P. K., Kumar, S., Khanduja, K. L. and Sharma, S. C. (2007) Whole body exposure to low-dose gamma radiation promotes kidney antioxidant status in Balb/c mice. J. Radiat. Res., 48,113.

Pollycove, M. (2004) Radiobiological basis of low-dose irradiation in prevention and therapy of cancer. 14 ${ }^{\text {th }}$ Pacific Basin Nuclear Conference. 2004 March 21025: Honolulu. HI, pp. 647-653.

Pollycove, M. and Feinendegen, L. E. (2003) Radiation-induced versus endogenous DNA damage: possible effect of inducible protection responses in mitigating endogenous damage. Hum. Exp. Toxicol., 22, 290.

Egypt. J. Rad. Sci. Applic., Vol. 24, No. 1 (2011) 
Sander, S., Chakraborty, A. and Chatterjee, M. (1996) Comparative effectiveness of vitamin $\mathrm{D}_{3}$ and dietary vitamin $\mathrm{E}$ on peroxidation of lipid and enzymes of the hepatic antioxidant system in Sprague-Dawley rats. Int. J. Vitam. Nutr. Res., 66, 39 .

Scheuhammer, A. M. and Cherian, M. G. (1986) Quantification of metallothioneins by a silver-saturation method. Toxicol. Appl. Pharmacol., 82, 417.

Shiraishi, N., Hiromochi, Y., Yoshihiro, T., Shintarooh, K., Hidehiro, H., Keiji, H. and Kaname, A. (1986) Increased metallothionein content in rat liver and kidney following X-irradiation. Toxicol. .Appl. Pharmacol., 85, 128.

Sorenson, J. R. J (1978) Evaluation of altered copper, iron, magnesium, manganese and zinc concentrations in rheumatoid arthritis. Inorgan. Perspect. Biol. Med., 2, 1.

UNSCEAR. (1986) Genetic and somatic effects of ionizing radiation, 1986 report to the General Assembly, with annexes. New York, United Nations.

Wall, B. F., Kendall, G. M., Edwards, A. A., Bouffler, S., Muihead, C. R. and Meara, J. R. (2006) What are the risks from medical X-rays and other low dose radiation? Brit. J. Radiol., 79, 285.

Wang, B., Ohyama, H., Shang, Y., Tanaka, K., Aizawa, S., Yukawa, O. and Hayata, I. (2004) Adaptive response in embryogenesis: V. Existence of two efficient dose-rate ranges for $0.3 \mathrm{~Gy}$ of priming irradiation to adapted mouse fetuses. Radiat. Res., 161, 264.

Yoshioka, T., Kawada, K., Shimada, T. and Mori, M. (1979) Lipid peroxidation in maternal and cord blood and protective mechanism against activated oxygen toxicity in the blood. Am. J. Obstet. Gynecol., 135, 372.

(Received: 21/11/2011;

accepted: 04/01/2012)

Egypt. J. Rad. Sci. Applic., Vol. 24, No. 1 (2011) 


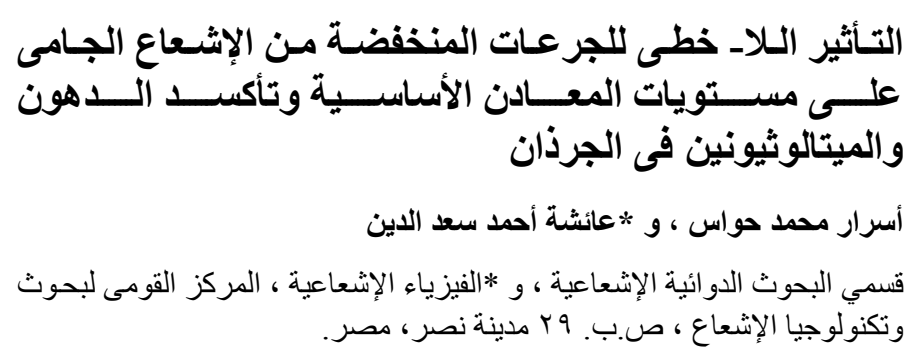

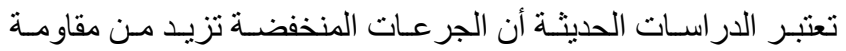

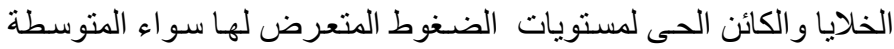

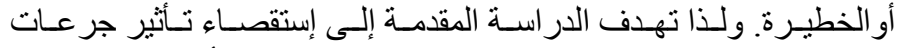

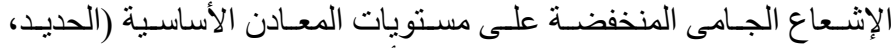

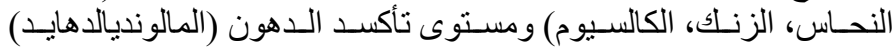

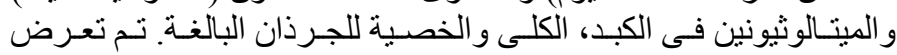

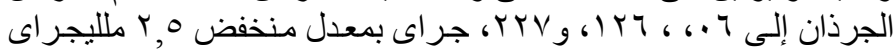

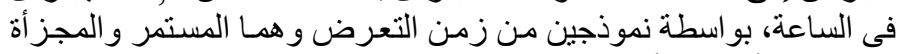

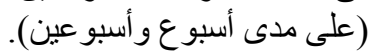

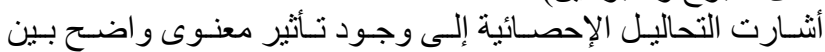

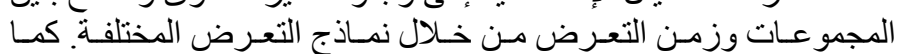

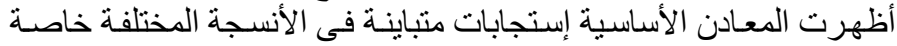

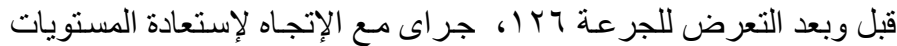

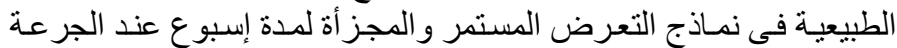

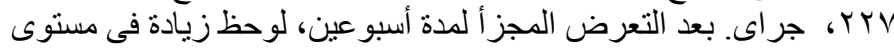

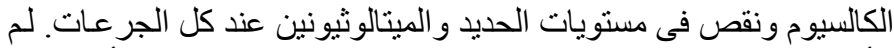

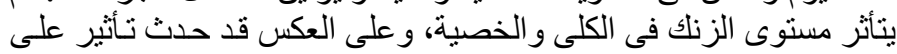

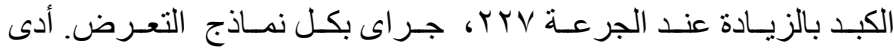

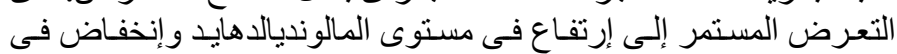

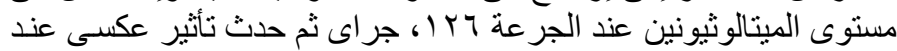

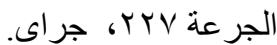

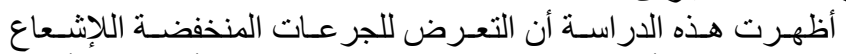

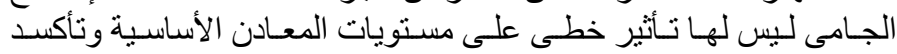

الدهون و الميتالوثيونين.

Egypt. J. Rad. Sci. Applic., Vol. 24, No. 1 (2011) 